International Journal of Engineering \& Technology, 7 (2.29) (2018) $865-870$
International Journal of Engineering \& Technology
SPC
Website: www.sciencepubco.com/index.php/IJET
Research paper

\title{
Perceptions Passengers on Service Quality: Public Transport in Kuala Lumpur
}

\author{
Hamza Imhimmed Mohamed Irtema ${ }^{1,4^{*}}$, Amiruddin Ismail ${ }^{1,2}$, Muhamad Nazri Borhan ${ }^{1,2}$, \\ Hassan M Abdelsalam ${ }^{1,}$ Abdurauf.B.Z Alshetwi ${ }^{1,5}$, Shaban Ismael Albrka ${ }^{8,}$ Abdalrhman Milad ${ }^{1,}$ Buseif Mo- \\ hashhash $^{1,}$ Aboubaker Y. Y. Alfakhri ${ }^{1,}$ Amsori Muhammad Das ${ }^{1,7}$, \\ Hussin A.M. Yahia ${ }^{6}$, Allam Musbah Al Allam ${ }^{3}$
}

\author{
${ }^{I}$ Centre for Smart and Sustainable Township Research Centre (Sutra), Faculty of Engineering \& Built Environment, Universiti Ke- \\ bangsaan Malaysia, Malaysia. \\ ${ }^{2}$ Programme of Civil Engineering, Faculty of Engineering \& Built Environment, Universiti Kebangsaan Malaysia, Malaysia. \\ ${ }^{3}$ Department Of Civil Engineering, Univversiti Tun Hussein Onn Malaysia (UTHM), 86400 Batu Pahat Johor, Malaysia. \\ ${ }^{4}$ Department of Civil Engineering, Sebha University, Sabha, Libya. \\ ${ }^{5}$ Department of civil Engineering Higher Institute of Science and Technology Zahra Libya. \\ ${ }^{6}$ Department of civil Engineering Middle East College, Knowledge Oasis Muscat. \\ ${ }^{7}$ Department of Civil and Environments Engineering, Universitas Batanghari,Jambi, Kota Jambi, 36122, Indonesia. \\ ${ }^{8}$ Civil Engineering Department, Near East University, Nicosia/TRNC, North Cyprus, Mersin 10, Turkey. \\ *Corresponding Author E-Mail: Hamzairtemih@Gmail.Com \& Hamzairtemih@siswa.ukm.edu.my
}

\begin{abstract}
The quality of service is a measurement of the level of service provided against the expectations of customers. This research examines the behaviour of passengers using public transport with respect to the service quality of public transit. A questionnaire was answered by 412 passengers at one of the main railway stations, Kuala Lumpur Sentral. Empirical data were extracted based on the information collected from the survey. Structural equation modelling was used to examine the measurement model. The findings of the study reveal that public transport passengers are significantly influenced by service attributes, for example, vehicle safety, cleanliness of the facility, and management of complaints. These findings identify the important service attributes that public transportation services in Kuala Lumpur need to prioritise. This study will help ascertain whether service quality meets or exceeds the expectations of the passengers.
\end{abstract}

Keywords: Kuala Lumpur; service quality; public transport; and Structural Equation Modelling

\section{Introduction}

In today's world, the success of a public transit system is associated with the ability of the system to attract and retain passengers. Therefore, the quality of the service provided is important, since an increase or decrease in the quality of service will impact the satisfaction of passengers, thus influencing the usage of the system. Service quality, in this study, is associated with a set of attributes that describe public transport services. 'Customers are the sole judges of service quality' (1), and a number of other researchers agree with this theory. Service quality is an important factor to consider for city transport planners while planning urban growth. Generally, passengers are questioned about their expectations of the service.

The attributes of service quality that need improvement are highlighted based on the importance of the attributes and the level of satisfaction experienced by the passengers $(2,3)$. Hence, the measure of service quality from the passengers' perspective will depend on their perception of the individual attributes of the service rendered. The service quality of public transport plays a major part in affecting the public's daily mode of transportation. The central and local governments initiate sustainable transport policies to avoid congestion in cities because it adversely affects the environment and climate. However, the policies also need to consider the requirements of the passengers. Therefore, it is important to identify and quantify the variables that most influence a passenger's decision to use public transportation. The policies must be devised based on the categories or socio-economic strata of the passengers or potential users who will be affected by the policies; they believe that issues to improve the quality of service must be addressed to attract more customers. In Malaysia and some other developing nations, the inadequate quality of their public transit system is one of the major issues faced by city planners and government.

In Malaysia, construction of a high quality public transportation system is difficult due to the continuous growth of its urban population. Besides, Malaysia needs to focus on ensuring the basic requirements of transportation to support its economy growth and boost investment. There has been an improvement in the public transport system in Malaysia, thus reducing the number of private vehicles. (4) the traffic congestion has reduced together with sound and air pollution. However, with the increase in number of people using private cars, Kuala Lumpur has the lowest number of 
public transport passengers in Asia. The Kuala Lumpur Structure Plan 2020 (5) reported that only $20 \%$ of the total passengers in Kuala Lumpur used public transport, whereas $80 \%$ used private transport. This situation affects the urban poor who cannot afford private cars, but need an affordable, accessible, and reliable mode of transportation to distant places where employment opportunities are available. The objective of this study is to explore the perception of the quality of service concerning the public transportation system in Kuala Lumpur. The findings can assist the public transport administrators marketers formulate efficacious strategies to fulfil passengers' needs, consequently, decreasing the usage of private cars and raising the passengers number of public transport.

\section{Literature Review}

\subsection{Service quality}

Service quality is a measurement of the servicing standard provided against anticipations of customer. An organisation's service quality must constantly comply with its customers' expectations (6-8). The extent to which service performance is compliant with the customers' expectations affects customers' satisfaction levels. The SERVQUAL scale (9) focuses on the disconfirmation of the expectancy model (10) to measurement the service quality. The SERVQUAL scale consists of 22 attributes that are categorised into 5 dimensions: assurance, tangibility, responsiveness, reliability, and empathy. However, these five dimensions and 22 attributes are considered inappropriate for certain kinds of service businesses (11). Thus, the scale needs to be customized based on the specific features of the service that is being studied. Literature reviews show that service quality is a critical determinant of behavioural intention $(12,13)$.

Past research shows that service quality directly impacts behavioural intention $(14,15)$ and indirectly influences behavioural intention based on the satisfaction level $(11,16,17)$ and perceived value (18). In the context of public transportation, it has been verified that there is a direct positive relationship between quality of service and behavioural intention (19). (6) used 9 factors and 54 attributes to examine the service quality of paratransit service in Bandung, Indonesia. The 9 factors are the environmental impact, comfort, safety, customer service, information, ticket fare, reliability, accessibility, and availability. The study explored users' perception of the service quality and the overall satisfaction level. The researchers believed that the results would predict the position of the service against private vehicles in Bandung city, Indonesia. The results obtained showed that service quality positively affected the overall satisfaction of passengers. Consequently, overall satisfaction positively influenced customer loyalty. (20) examined the factors of public transportation service quality based on the SERVQUAL model. The factors included reliability, tangibility, assurance, responsiveness, and empathy. The factors were analysed based on the difference in quality between passengers' expectations and their perceptions.

$(21,22)$ examined road safety factors for the management of bus services by using the Delphi method and Kendall's algorithm. They considered factors related to the management of bus services: drivers (training, skills, behaviour, and performance evaluation), vehicles (maintenance and advanced devices), and roads (road and traffic safety issues). Another study, on public transport services, examined vehicle comfort, station comfort, tickets price, accessible on time, transport reliability, information, spatially arrival, the employees of mass public transport service in Belgrade (23). (24) examined the variables that influence the public transportation quality based on an ordered probit analysis. The analysis considered relevant attributes, including the time taken to walk to the initial bus stop, waiting time, journey time, safety features in the vehicle, deviation from the optimal route, level of comfort experienced when stopping and restarting the vehicle, comfort experienced during the course of journey, cleanliness of the vehicle, bus fare, vehicle quality, courtesy shown by the bus driver, and reliability of the vehicle. Another study by (25) examined the quality of service of an urban bus based on twelve variables: cleanliness, information, fare, reliability, temperature proximity, speed, frequency, space, accessibility, courtesy and safety. Next, these indicators were divided into three groups: comfort, serving, and private factors. These categories were analysed using structural equation modelling (SEM).

(26) used SEM to examine the relationship between the service quality of the intercity bus system and the behavioural intentions of passengers in Taiwan. Service quality was analysed based on the SERVQUAL model (27). The twenty indexes of service quality were categorised into four groups: concrete service tools (six items), serving suitability (five items), supporting the management operating (three items), and interaction with passengers (six items) On the other hand, (26) used confirmatory factor analysis (CFA) to determine the existing state of the variables before the SEM analysis was conducted. The twenty attributes of service quality were categorized using exploratory factor analysis (EFA) into four groups: onboard kindness (nine items), the behaviour of the crew (five items), and operational achievement (four items), and station achievement (four items). (28) evaluated the categories using SEM. The findings showed that at a statistical significance level, quality of service was the variable that influenced the contentment of interurban ridership. (29) examined the factors of service quality for the sightseeing tour buses in Thailand. Twenty-seven parameters were used as a standard for assessing and developing service, were categorised using exploratory factor analysis (EFA) into three groups: management, the attitude of crews, and drivers, and vehicles, thereafter, confirmatory factor analysis (CFA) was used to assert the structure of factor. (30) studied the service quality of public transport system in Greece using twenty-three attributes. The attributes were grouped into four categories: general features of the public transit system, vehicles, stations and stops, and transport points based on the Handbook for Measuring Customer contentment, and Quality of Service (7). In the present study, the service quality of public transport in Kuala Lumpur is evaluated using two factors with thirteen attributes. The two factors are physical environment and core service. In this research, the service attributes used by (19) are customized to suit the service features of the public transport system in Kuala Lumpur.

\section{Methodology}

A questionnaire-based survey was conducted in a busy part of Kuala Lumpur Sentral. The main railway station is located in Kuala Lumpur (KL) Sentral, a transit hub. Figure 1 shows KL Sentral station and illustrates the public transport routes in Kuala Lumpur. KL Sentral opened on 16 April 2001 and soon grew to be the main intercity railway station. It connects most of the passenger railway lines within the city and simultaneously connects several intercity trains travelling to different parts of Peninsular Malaysia and Singapore (31). Being an international business centre, Kuala Lumpur Sentral is important for residents and visitors. Initially, this enormous self-sustaining and well-planned transport system was designed to support Malaysia's largest transportation hub, Stesen Sentral, to promote and increase the use of public transportation. Besides reducing the country's carbon footprint and serving as a green initiative, the use of public transportation will significantly reduce traffic within Kuala Lumpur Sentral (32). This research focuses on the items of service quality. 


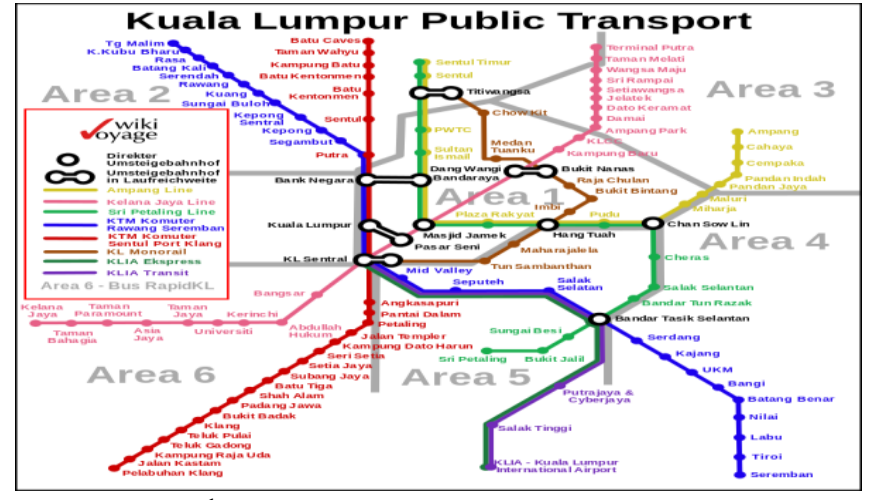

Fig. 1: Maps of Public Transport in Kuala Lumpur

Source: Kuala Lumpur Public Transport.svg (2016)

\subsection{Measures}

In this study, the items associated with service quality are measured based on the study conducted by (19). Table 1 shows the number of indexes for each variable in conjunction with the sources used to generate the indicators. A questionnaire-based survey is used to study 13 items of service quality. For example, to assess the service quality frequency in public transport, a fivepoint Likert scale is employed. The Likert scale ranges from 'strongly disagree (1)' to 'strongly agree (5)'. The measurement of all 13 items of service quality is included in Appendix A.

Table 1: Number of Indicators and Sources for Construct Measures

\begin{tabular}{|c|c|c|}
\hline Constructs & Number of Indicators & Source \\
\hline Service quality & 13 & $(7,19)$ \\
\hline
\end{tabular}

\subsection{Sample and Data Collection}

In January 2016, data were collected using a questionnaire-based survey that was conducted among public transit passengers in Kuala Lumpur Sentral. Among the 450 questionnaires that were distributed, those with incomplete responses were deleted and 412 responses were obtained. The response rate was $91.5 \%$. The usable sample consisted of 251 male respondents (60.9\%) and 161 female respondents $(39.1 \%)$. Hence, majority of the respondents are males. Additionally, the age of $52.7 \%$ of the respondents is between 21 to 30 years; $37.4 \%$, between 31 to 40 years; $6.3 \%$, between 41 to 50 years; and $3.4 \%$, below 20 years of age. The sample did not consist of any respondents exceeding the age of 51 years. The participants were also asked to mention their location of residence. Of the respondents, $65.8 \%$ belong to Kuala Lumpur, while the remaining $34.2 \%$ belong to other states. Regarding the occupation of the participants, $57.5 \%$ are students, $26 \%$ are employed full-time, $10.2 \%$ are employed part-time, $5.6 \%$ are involved in different kinds of occupations, and $0.7 \%$ are unemployed. With regard to the income profile of the participants, $42.7 \%$ of the respondents did not specify their income range, $18.2 \%$ earned RM7000 or more, $4.1 \%$ earned between RM6000 and RM7000, 5.1\% earned between RM5000 and RM6000, 5.3\% earned between RM4000 and RM5000, $15.5 \%$ earned between RM3000 and RM4000, and 9\% earned between RM2000 and RM3000. The frequencies and percentages of the demographic variables are displayed in Table 2 .

Table2: Sample Profile

Table2: Sample Profile
\begin{tabular}{|l|l|l|}
\hline Group & Frequency & Percentage \\
\hline Gender & & \\
\hline Male & 251 & 60.9 \\
\hline Female & 161 & 39.1 \\
\hline Age & & \\
\hline Less than 20 years old & 14 & 3.4 \\
\hline 21 to 30 years old & 217 & 52.7 \\
\hline 31 to 40 years old & 154 & 37.4 \\
\hline 41 to 50 years old & 26 & 6.3 \\
\hline More than 51 years old & 1 & .2 \\
\hline Location & & \\
\hline
\end{tabular}

\begin{tabular}{|l|l|l|}
\hline Kuala Lumpur & 271 & 65.8 \\
\hline Other state & 141 & 34.2 \\
\hline Occupation & & \\
\hline Full-time employment & 107 & 26.0 \\
\hline Part-time employment & 42 & 10.2 \\
\hline Unemployment & 3 & .7 \\
\hline Student & 237 & 57.5 \\
\hline Others & 23 & 5.6 \\
\hline Income Range & & \\
\hline RM 2000 - RM 3000 & 37 & 9.0 \\
\hline RM 3000 - RM 4000 & 64 & 15.5 \\
\hline RM 4000 - RM 5000 & 22 & 5.3 \\
\hline RM 5000 - RM 6000 & 21 & 5.1 \\
\hline RM 6000 - RM 7000 & 17 & 4.1 \\
\hline RM 7000 and above & 75 & 18.2 \\
\hline I don't wish to say & 176 & 42.7 \\
\hline & &
\end{tabular}

\section{Results}

\subsection{Measurement Model (CFA)}

To ensure accuracy, operationalization of the constructs is important (33). To determine theoretical accuracy, several researchers have constructed different scales. Although there are a number of different scales, researchers often find it difficult to acquire a set of established scales. Therefore, they develop new scale measurements or customize the existing scales as per their requirements SEM analysis is based on item selection used for measuring the constructs (33). This study is based on the individual CFA model for service quality. It is the only second-order construct used in the study and acts as an overall measurement model for individual and the research variables. The following subsections expound the evolution operation for the measurement model. The results obtained after testing the unit-dimensionality of each construct are presented using the AMOS 18.0 software.

\subsection{CFA Model for Service Quality}

This study used 13 items to measure the two first-order constructs in SQ, namely, core service (SQCS) and physical environment (SQPE). Appendix B shows the initial SQ models including the 13 associated items.

\subsection{Standardized Loadings of the Items}

The constructs in SQ are based on the CFA model. Table 3 displays the items deleted from the model and the recalculated factor loadings for the undeleted items.

Table3: Initial Standardized Factor Loadings of the SQ Items in the CFA Model

\begin{tabular}{|l|l|l|l|l|}
\hline Construct & Item & $\begin{array}{l}\text { Initial } \\
\text { Factor } \\
\text { Loading }\end{array}$ & $\begin{array}{l}\text { Item De- } \\
\text { leted }\end{array}$ & $\begin{array}{l}\text { Second } \\
\text { Factor } \\
\text { Loading }\end{array}$ \\
\hline \multirow{4}{*}{$\begin{array}{l}\text { Core Service } \\
\text { (SQCS) }\end{array}$} & SQCS1 & 0.339 & Deleted & \\
\cline { 2 - 5 } & SQCS2 & 0.71 & & 0.704 \\
\cline { 2 - 5 } & SQCS3 & 0.265 & Deleted & \\
\cline { 2 - 5 } & SQCS4 & 0.754 & & 0.761 \\
\cline { 2 - 5 } & SQCS5 & 0.743 & & 0.754 \\
\cline { 2 - 5 } & SQCS6 & 0.731 & & 0.723 \\
\cline { 2 - 5 } & SQCS7 & 0.698 & & 0.687 \\
\hline \multirow{4}{*}{$\begin{array}{l}\text { Physical Envi- } \\
\text { ronment }\end{array}$} & SQPE1 & 0.84 & & 0.842 \\
\cline { 2 - 5 } & SQPE2 & 0.877 & & 0.889 \\
\cline { 2 - 5 } & SQPE3 & 0.851 & & 0.85 \\
\cline { 2 - 5 } & SQPE4 & 0.353 & Deleted & \\
\cline { 2 - 5 } & SQPE5 & 0.805 & & 0.796 \\
\cline { 2 - 5 } & SQPE6 & 0.299 & Deleted & \\
\hline
\end{tabular}

Results from the standardised loadings for model items are shown in Table 3. It shows that the factor loadings of the four items, namely, SQCS1, SQCS3, SQPE4, and SQPE6 are below the cutoff level of 0.5 . Based on the results, these items were deleted from the model. The reviewed models with the residual nine items are retested to assure the stability of the structure factor. The value 
of the second standardised factor loadings for all items was found to be more than 0.5 and ranged between 0.687 and 0.889 (Figure $3)$. Thus, deletion of items was not required.

\subsection{Reliability and Convergent Validity}

After conducting the unit-dimensionality of the structures, it is important to evaluate the reliability and validity of the individual constructs. Reliability is evaluated using the following: (1) Cronbach's alpha, (2) construct reliability (CR), and (3) average variance extracted (AVE). For testing the validity, construct convergent and discriminant are used. The results for the residual nine items are showing in Table 4. It includes Cronbach's alpha value and convergent validity for the adjusted CFA model for service quality.

Table4: Results of Cronbach Alpha and Convergent Validity for Service Quality CFA Model

\begin{tabular}{|c|c|c|c|c|c|}
\hline \multirow{2}{*}{ Construct } & \multirow{2}{*}{ Items } & \multirow[b]{2}{*}{$\begin{array}{l}\text { Internal } \\
\text { Reliabil- } \\
\text { ity } \\
\text { Cronbac } \\
\text { h } \\
\text { Alpha } \\
\end{array}$} & \multicolumn{3}{|c|}{ Convergent validity } \\
\hline & & & $\begin{array}{l}\text { Final } \\
\text { Factor } \\
\text { Load- } \\
\text { ing }\end{array}$ & $\begin{array}{l}\text { Average } \\
\text { Variance } \\
\text { Extract- } \\
\text { ed } \\
(\mathrm{AVE})^{\mathrm{a}}\end{array}$ & $\begin{array}{l}\text { Compo- } \\
\text { site Reli- } \\
\text { ability } \\
(\mathrm{CR})^{\mathrm{b}}\end{array}$ \\
\hline \multirow[t]{7}{*}{$\begin{array}{l}\text { Core Ser- } \\
\text { vice (SQCS) }\end{array}$} & $\begin{array}{l}\text { SQCS } \\
1\end{array}$ & \multirow{7}{*}{0.847} & 0.339 & \multirow{7}{*}{0.528} & \multirow{7}{*}{0.848} \\
\hline & $\begin{array}{l}\text { SQCS } \\
2\end{array}$ & & 0.704 & & \\
\hline & $\begin{array}{l}\text { SQCS } \\
3\end{array}$ & & 0.265 & & \\
\hline & $\begin{array}{l}\text { SQCS } \\
4\end{array}$ & & 0.761 & & \\
\hline & $\begin{array}{l}\text { SQCS } \\
5\end{array}$ & & 0.754 & & \\
\hline & $\begin{array}{l}\text { SQCS } \\
6\end{array}$ & & 0.723 & & \\
\hline & $\begin{array}{l}\text { SQCS } \\
7\end{array}$ & & 0.687 & & \\
\hline \multirow{6}{*}{$\begin{array}{l}\text { Physical } \\
\text { Environ- } \\
\text { ment } \\
\text { (SQPE) }\end{array}$} & $\begin{array}{l}\text { SQPE } \\
1\end{array}$ & \multirow{6}{*}{0.908} & 0.842 & \multirow{6}{*}{0.714} & \multirow{6}{*}{0.909} \\
\hline & $\begin{array}{l}\text { SQPE } \\
2\end{array}$ & & 0.889 & & \\
\hline & $\begin{array}{l}\text { SQPE } \\
3\end{array}$ & & 0.85 & & \\
\hline & $\begin{array}{l}\text { SQPE } \\
4\end{array}$ & & 0.353 & & \\
\hline & $\begin{array}{l}\text { SQPE } \\
5\end{array}$ & & 0.796 & & \\
\hline & $\begin{array}{l}\text { SQPE } \\
6\end{array}$ & & 0.299 & & \\
\hline
\end{tabular}

${ }^{a}$ : Average Variance Extracted $=$ (summation of the square of the factor loadings $) /\{$ (summation of the square of the factor loadings) + (summation of the error variances).

${ }^{\mathrm{b}}$ : Composite reliability $=$ (square of the summation of the factor load ings) $/$ (square of the summation of the factor loadings) + (square of the summation of the error variances) $\}$.

${ }^{c}$ denotes for discarded item due to insufficient factor loading below cut off 0.5

Only four items were deleted, which is a relatively small number when compared to the total of 13 items in the construct. Hence, the elimination of these items does not significantly impact the conceptualisation of the construct's content. As shown in Table 4, the factor loading values are considerably high within the range of 0.687 to 0.889 , which means that the factors have been conserved by these indexes. Table 4 shows the AVE value that depicts the total variance in the indexes. Value of the latent structure is 0.528 for SQCS and 0.714 for SQPE. Both values are higher than the cut-off value of 0.5 (34). The composite reliability value is associated with the degree to which the construct indicators show the latent construct, that is 0.848 for SQCS and 0.909 for Physical Environment SQPE. The achieved values are higher than the recommended value of 0.6 (35). Cronbach's alpha reflects the freedom of error of a measure. For SQCS, the value is 0.847 and for
SQPE the value is 0.908 . These values are higher than the recommended value of 0.7 (34).

\subsection{Goodness of Fit Indices (GFI)}

The goodness-of-fit (GOF) results show that the chi-square is significant at 0.000 levels as displayed in Table 5. If the sample size exceeds 200 , the absolute fit index of least contradiction in chi-square can be neglected (36). The GFI value is found to be 0.970 which is higher than the recommended value of 0.9 (37). After making adjustments to the degrees of freedom relative to the number of variables, the adjusted GFI (AGFI) value is 0.948 which is higher than the recommended value of 0.80 (38). The model predicts $95 \%$ of the variances and covariance in the survey data. The values of comparative fit index $(\mathrm{CFI})=0.986$, Tucker Lewis Index $(\mathrm{TLI})=0.980$, and incremental Fit Index $(\mathrm{IFI})=0.986$ indices exceeded the threshold value of 0.9. Therefore, the model proves to be a good fit $(33,35,39,40)$. Moreover, the root-meansquare error of approximation (RMSEA) is 0.052 which is lower than the recommended value of 0.1 (41). The relative CMIN/DF is 2.122 which is lower than 5 , which shows that the model is a good fit (35). The adjusted CFA model for SQ fits the data appropriately. Therefore, no modifications are required.

Table 5: GOF Indices of Modified Measurement Model for Service Quality

\begin{tabular}{|l|l|l|l|}
\hline Fit index & Modified Model & Recommended values & Source \\
\hline $\mathrm{df}$ & 26 & & \\
\hline CMIN $\left(\chi^{2}\right)$ & 55.184 & & \\
\hline $\mathrm{p}-$ value & 0.001 & $>0.05$ & \\
\hline$\chi^{2} / \mathrm{df}$ & 2.122 & $\leq 5.00$ & $(35)$ \\
\hline GFI & 0.970 & $\geq 0.90$ & $(37)$ \\
\hline AGFI & 0.948 & $\geq 0.80$ & $(38)$ \\
\hline CFI & 0.986 & $\geq 0.90$ & $(35,39)$ \\
\hline TLI & 0.980 & $\geq 0.90$ & $(33,40)$ \\
\hline IFI & 0.986 & $\geq 0.90$ & $(33,40)$ \\
\hline RMSEA & 0.052 & $\leq 0.10$ & $(41)$ \\
\hline
\end{tabular}

\subsection{Discriminant validity}

Discriminant validity is conducted to examine the extent to which one item is different from the other structures. To achieve a significant discriminant validity, the correlations between the factors in the measurement model should not be greater than 0.85 (42). To test the validity, a comparison of the correlation between the constructs is extracted in conjunction with the square root of the average variance (43). The discriminant validity of the modified measurement model for SQ is shown in Table 6.

Table 6: Discriminant validity of Modified Measurement Model for Service Quality

\begin{tabular}{|l|l|l|}
\hline & SQCS & SQPE \\
\hline Core Service (SQCS) & 0.726 & \\
\hline Physical Environment (SQPE) & 0.617 & 0.845 \\
\hline
\end{tabular}

Note: Diagonals represent the square root of the average variance extracted while the other entries represent the square correlations.

The value of inter-correlations between SQCS and SQPE was found to be 0.617 . This value is lower than the threshold of 0.85 . As showing in Table 6, the correlation is lower than the square root of the average variance extracted by the indexes. Thus, the discriminant validity is satisfactory between the factors. Based on the results achieved for goodness of fit, the convergent and discriminant validity of the modified measurement model and the overall reliability and validity of the modified measurement scale has been proved. It is a reliable method to assessment the constructs and the related items in SQ. Figure 2 shows the adjusted and final measurement model with the nine items and their standardised factor loadings. 


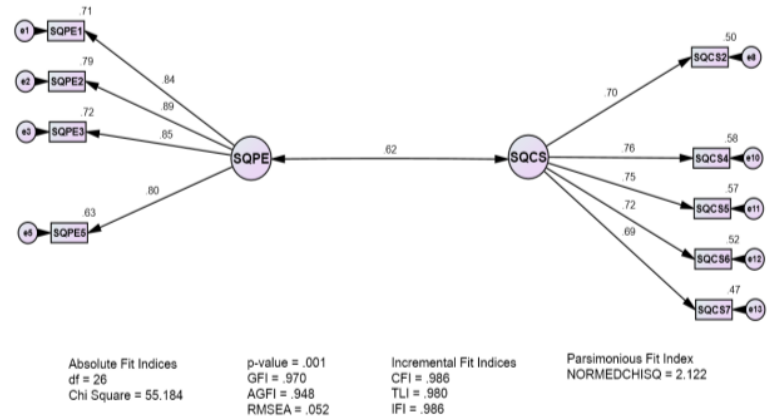

Fig.2: Modified Measurement Model for Service Quality with Remaining 9 Items

\section{Discussion and conclusion}

This research has explored the behaviour of public transportation passengers with respect to the service quality of public transport. Compared to past research, this research examines the role of passenger involvement in their experience while using public transit services. The data were obtained from a questionnairebased survey conducted among passengers in Kuala Lumpur Sentral. The effect of psychological elements that influence the perception of service quality in public transportation have also been addressed $(19,29,44)$.The results reveal important implications for public transit organisations and the findings are similar to those obtained in the study conducted by Lai and Chen (2011).

Service quality in this study refers to the passengers' evaluation of the service characteristic of public transportation services, for example, the generic features of the public transit system, vehicles, stations and stops, and transportation points (30). Enhancement in service quality influences customer satisfaction and their loyalty. This results in an increase of goodwill and repetition of customers which leads to an increase in profits and revenue for the organisation $(19,28,44)$.

The results obtained from this research showed that service attributes, namely, vehicle safety, service cleanliness, and grievance management significantly influence the passengers of public transportation. These findings provide valuable information for the public transit system in Kuala Lumpur. They guide the system in prioritising serious service characteristic and ensuring that service quality meets or overrides the expectancies of the passengers. Nevertheless, improving service quality is expensive and such costs are normally borne by passengers through an increase in ticket fare. This might offset the benefits for passengers.

In this research, the results show that involvement is influenced by evaluations made by the passengers about the service quality of the public transit system in Kuala Lumpur. If the passengers are pleased with the public transportation system, their involvement will increase (19). Increased involvement may encourage more people to use the public transportation system. Furthermore, this research focuses on factors of quality. Future studies can be conducted to analyse passengers' satisfaction level and loyalty towards public transport.

\section{Acknowledgement}

The work presented in this paper was supported by Centre for Smart and Sustainable Township Research Centre (SUTRA), Faculty of Engineering \& Built Environment, Universiti Kebangsaan Malaysia,(UKM) Malaysia, Under the Project FRGS/1/2017/TK08/UKM/01/1 and GUP-2016-019.

\section{References}

[1] Berry LL, Zeithaml VA, Parasuraman A. Five imperatives for improving service quality. MIT Sloan Management Review. 1990;31(4):29.
[2] Phanikumar C, Maitra B, editors. Modeling willingness-to-pay values for rural bus attributes under different trip purposes. Journal of the Transportation Research Forum; 2010.

[3] Li Z, Hensher DA. Crowding and public transport: a review of willingness to pay evidence and its relevance in project appraisal. Transport Policy. 2011;18(6):880-7.

[4] MALAYSIA MMS. Department of Statistics, Malaysia. 2014.

[5] Hall KLC. Kuala Lumpur structure plan 2020. Kuala Lumpur: KLCH. 2004.

[6] Joewono TB, Kubota H. User satisfaction with paratransit in competition with motorization in indonesia: anticipation of future implications. Transportation. 2007;34(3):337-54.

[7] Administration USFT, Corporation TD, International M, Program TCR, Systematics C. A Handbook for Measuring Customer Satisfaction and Service Quality: Transportation Research Board; 1999.

[8] Kittelson, Associates, Administration USFT, Program TCR, Corporation TD. Transit capacity and quality of service manual: Transportation Research Board; 2003.

[9] Parasuraman A, Zeithaml VA, Berry LL. A conceptual model of service quality and its implications for future research. the Journa of Marketing. 1985:41-50.

[10] Oliver RL. A cognitive model of the antecedents and consequences of satisfaction decisions. Journal of marketing research. 1980:4609.

[11] Cronin Jr JJ, Taylor SA. Measuring service quality: a reexamination and extension. The journal of marketing. 1992:5568.

[12] Cronin JJ, Brady MK, Hult GTM. Assessing the effects of quality, value, and customer satisfaction on consumer behavioral intentions in service environments. Journal of retailing. 2000;76(2):193-218.

[13] Huang YK, editor THE EFFECT OF AIRLINE SERVICE QUALITY ON PASSENGERS'BEHAVIOURAL INTENTIONS USING SERVQUAL SCORES: A TAIWAN CASE STUDY. Proceedings of the Eastern Asia Society for Transportation Studies; 2009: Eastern Asia Society for Transportation Studies.

[14] Chiao Y-C. An integrated model for the effects of perceived product, perceived service quality, and perceived price fairness on consumer satisfaction and loyalty. 2001.

[15] Al-Rousan MR, Mohamed B. Customer loyalty and the impacts of service quality: The case of five star hotels in Jordan. International journal of human and social sciences. 2010;5(13):886-92.

[16] Stank TP, Goldsby TJ, Vickery SK. Effect of service supplier performance on satisfaction and loyalty of store managers in the fast food industry. Journal of Operations Management. 1999;17(4):429-47.

[17] Hellier PK, Geursen GM, Carr RA, Rickard JA. Customer repurchase intention: A general structural equation model. European journal of marketing. 2003;37(11/12):1762-800.

[18] Dodds WB, Monroe KB, Grewal D. Effects of price, brand, and store information on buyers' product evaluations. Journal of marketing research. 1991:307-19.

[19] Lai W-T, Chen C-F. Behavioral intentions of public transit passengers - The roles of service quality, perceived value, satisfaction and involvement. Transport Policy. 2011;18(2):318-25.

[20] Susnienè D. Quality approach to the sustainability of public transport. Transport. 2012;27(1):102-10.

[21] Cafiso S, Di Graziano A, Pappalardo G. Using the Delphi method to evaluate opinions of public transport managers on bus safety. Safety science. 2013:57:254-63.

[22] Cafiso S, Di Graziano A, Pappalardo G. Road safety issues for bus transport management. Accident Analysis \& Prevention. 2013;60:324-33

[23] Filipović S, Tica S, Živanović P, Milovanović B. Comparative analysis of the basic features of the expected and perceived quality of mass passenger public transport service in Belgrade. Transport. 2009;24(4):265-73

[24] Dell'Olio L, Ibeas A, Cecin P. The quality of service desired by public transport users. Transport Policy. 2011;18(1):217-27.

[25] de Oña J, de Oña R, Eboli L, Mazzulla G. Perceived service quality in bus transit service: a structural equation approach. Transport Policy. 2013;29:219-26.

[26] Lin J-H, Lee T-R, Jen W. Assessing asymmetric response effect of behavioral intention to service quality in an integrated psychological decision-making process model of intercity bus passengers: a case of Taiwan. Transportation. 2008;35(1):129-44.

[27] Parasuraman A, Berry LL, Zeithaml VA. Refinement and reassessment of the SERVQUAL scale. Journal of retailing. 1991;67(4):420. 
[28] Wen C-H, Lan L, Cheng H-L. Structural equation modeling to determine passenger loyalty toward intercity bus services. Transportation Research Record: Journal of the Transportation Research Board. 2005(1927):249-55.

[29] Jomnonkwao S, Ratanavaraha V. Measurement modelling of the perceived service quality of a sightseeing bus service: An application of hierarchical confirmatory factor analysis. Transport Policy. 2016;45:240-52.

[30] Tyrinopoulos Y, Antoniou C. Public transit user satisfaction: Variability and policy implications. Transport Policy. 2008;15(4):260-72.

[31] wonderful_malaysia. http://www.wonderfulmalaysia.com/. 2015.

[32] world_class_transportation_Hub http://www.klsentral.com.my/conn_main.aspx 2015 [cited 201530 sep 2015].

[33] Hair JF, Black WC, Babin BJ, Anderson RE, Tatham RL. Multivariate data analysis: Pearson Prentice Hall Upper Saddle River, NJ; 2006

[34] Nunnally JC, Bernstein IH, Berge JMt. Psychometric theory: JSTOR; 1967.

[35] Bagozzi RP, Yi Y. On the evaluation of structural equation models Journal of the academy of marketing science. 1988;16(1):74-94.

[36] Steiger JH. Structural model evaluation and modification: An interval estimation approach. Multivariate behavioral research. 1990;25(2):173-80.

[37] Hoyle R. The structural equation modeling approach. Basic concepts and fundamental issues. EnR. H. Hoyle. Structural Equation Modeling. 1995.

[38] Chau PY, Hu PJH. Information technology acceptance by individual professionals: A model comparison approach*. Decision sciences. 2001;32(4):699-719.

[39] Byrne BM. Structural equation modeling with EQS: Basic concepts, applications, and programming: Routledge; 2013

[40] Ho R. Handbook of univariate and multivariate data analysis and interpretation with SPSS: CRC Press; 2006

[41] Lomax RG, Schumacker RE. A beginner's guide to structural equation modeling: Routledge Academic New York, NY; 2012.

[42] Kline RB. Principles and practice of structural equation modeling. Guilford Press. New York. 2005:59.

[43] Fornell C, Larcker DF. Structural equation models with unobservable variables and measurement error: Algebra and statistics. Journal of marketing research. 1981:382-8.

[44] Suki NM. Passenger satisfaction with airline service quality in Malaysia: A structural equation modeling approach. Research in Transportation Business \& Management. 2014;10:26-32.

\section{Appendix A.}

Measurement

\begin{tabular}{|l|}
\hline Constructs \\
\hline Service Quality (SQ)(7, 19) \\
\hline A- Core service ( SQCS) \\
\hline SQCS1- General information facility \\
\hline SQCS2- Service facility hours \\
\hline SQCS3- Fare \\
\hline SQCS4- Service regularity \\
\hline SQCS5- Deals with Complaint \\
\hline SQCS6- Ticket selling network \\
\hline SQCS7- Staffs behaviour \\
\hline B- Physical Environment (SQPE) \\
\hline SQPE1- Facility sanitation \\
\hline SQPE2- Vehicle hygiene \\
\hline SQPE3- Vehicle security \\
\hline SQPE4- Security at terminals and stops \\
\hline SQPE5- Vehicle stability \\
\hline SQPE6- On board information facility \\
\hline
\end{tabular}

\section{Appendix B.}

Initial First Service Quality CFA model with all 13 items

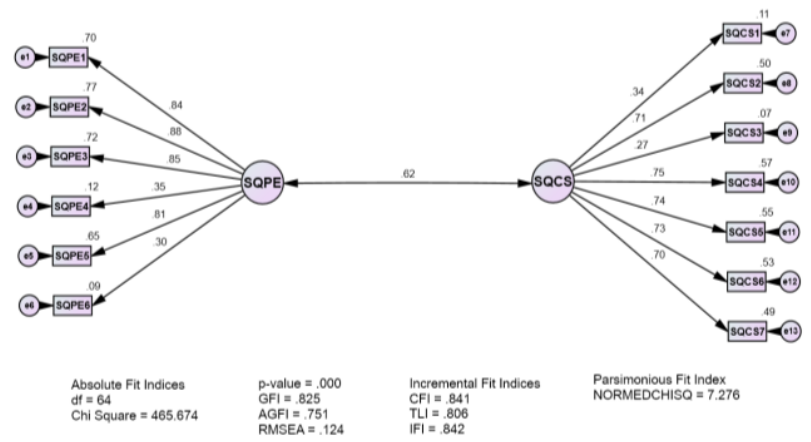

